\title{
Relationships Linking the Colour and Elemental Concentrations of Blossom Honeys with Their Antioxidant Activity: A Chemometric Approach
}

\author{
Monika Kędzierska-Matysek ${ }^{1}$, Anna Teter ${ }^{1}\left(\mathbb{D}\right.$, Małgorzata Stryjecka $^{2}$, Piotr Skałecki ${ }^{1}$ (D) Piotr Domaradzki ${ }^{1}$, \\ Michał Rudaś ${ }^{3}$ and Mariusz Florek ${ }^{1, *(D)}$ \\ 1 Department of Quality Assessment and Processing of Animal Products, University of Life Sciences in Lublin, \\ Akademicka 13, 20-950 Lublin, Poland; monika.matysek@up.lublin.pl (M.K.-M.); \\ anna.wolanciuk@up.lublin.pl (A.T.); piotr.skalecki@up.lublin.pl (P.S.); piotr.domaradzki@up.lublin.pl (P.D.) \\ 2 Institute of Agricultural Sciences, State School of Higher Education in Chełm, Pocztowa 54, \\ 22-100 Chełm, Poland; mstryjecka@pwsz.chelm.pl \\ 3 Central Laboratory of Research, University of Life Sciences in Lublin, Głęboka 30 D, 20-612 Lublin, Poland; \\ michal.rudas@up.lublin.pl \\ * Correspondence: mariusz.florek@up.lublin.pl; Tel.: +48-81-445-6621
}

\section{check for}

updates

Citation: Kędzierska-Matysek, M.; Teter, A.; Stryjecka, M.; Skałecki, P.; Domaradzki, P.; Rudaś, M.; Florek, M. Relationships Linking the Colour and Elemental Concentrations of Blossom Honeys with Their Antioxidant Activity: A Chemometric Approach. Agriculture 2021, 11, 702. https:// doi.org/10.3390/agriculture11080702

Academic Editor:

Alessandra Durazzo

Received: 26 June 2021

Accepted: 24 July 2021

Published: 26 July 2021

Publisher's Note: MDPI stays neutra with regard to jurisdictional claims in published maps and institutional affiliations.

Copyright: (c) 2021 by the authors. Licensee MDPI, Basel, Switzerland. This article is an open access article distributed under the terms and conditions of the Creative Commons Attribution (CC BY) license (https:// creativecommons.org/licenses/by/ $4.0 /)$
Abstract: The antioxidant activity of honey depends on the botanical origin, which also determines their physicochemical properties. In this study, a multivariate analysis was used to confirm potential relationships between the antioxidant properties and colour parameters, as well as the content of seven elements in five types of artisanal honey (rapeseed, buckwheat, linden, black locust, and multifloral). The type of honey was found to significantly influence most of its physicochemical properties, colour parameters, and the content of potassium, manganese and copper. Antioxidant parameters were shown to be significantly positively correlated with redness and concentrations of copper and manganese, but negatively correlated with the hue angle and lightness. The principal component analysis confirmed that the darkest buckwheat honey had the highest antioxidant activity in combination with its specific colour parameters and content of antioxidant minerals (manganese, copper and zinc). The level of these parameters can be potentially used for the identification of buckwheat honey.

Keywords: honey; physicochemical properties; colour; minerals; trace elements; ferric reducingantioxidant power assay; radical scavenging activity

\section{Introduction}

Bee products are valuable, natural foodstuffs with a wide range of beneficial properties for human health which are exploited in medicine [1]. Honey is the main product of extensive beekeeping in almost all countries worldwide. Owing to the biodiversity of plants and monocultures, multifloral and unifloral honeys are obtained [2,3].

The basis for the multifaceted use of honey in the human diet and therapy is its complex chemical composition, dominated by carbohydrates (70-80\%). In the honeys, enzymes, amino acids, vitamins, carotenoids, organic acids, phenolic acids, polyphenols, and flavonoids are present as well [4]. Honey also contains minerals essential for the functioning of the human body, with the content in fresh honey varying depending on the type, geographic origin, and method of honey harvesting and storage [3,5-8]. Excessively long storage affects the composition of honey and alters the biological activity of its components [3,7]. It should be underlined that honey also demonstrates antioxidant [2,9-11], immunomodulatory, and anti-inflammatory properties [12]. In view of the fact that the ageing process and degenerative diseases have their basis in free radicals, one way to counteract these changes and protect against free-radical diseases is to supply the body with appropriate antioxidants, which reduce the number of superoxide radicals 
in varying degrees. Substances with a beneficial effect on the human body include natural antioxidants counted among phenolic compounds [13].

Honey intended for human consumption must meet key criteria for content of fructose and glucose (sum of both), sucrose, moisture, water-insoluble content, electrical conductivity, free acid, diastase activity, and hydroxymethylfurfural [14]. One of the most important criteria is the level of 5-hydroxymethylfurfural (HMF $\leq 40 \mathrm{mg} \mathrm{kg}^{-1}$ ), due to the potential risk for bees and humans. Another parameter is the enzymatic activity of $\alpha$-amylase (diastase activity $\geq 8.0$ on the Schade scale) naturally occurring in honey. A high diastase number $(\mathrm{DN})$ and low content of 5-HMF are considered a guarantee of high-quality honey. Negative changes in honey are caused by the effects of high temperature during decrystallization and long-term storage in combination with high temperature and exposure to light [15-17].

The botanical origin of honey determines its diversity in terms of physicochemical, organoleptic and biological properties [5-7]. The type of honey is distinguished by a wide range of colours, a characteristic flavour and aroma, chemical composition, form of crystallization, and specific preventive properties against individual disease conditions. Owing to these varied attributes, each consumer can choose honey according to individual needs and preferences. At the same time, due to the rich content of different sugars, honey can be a healthy substitute for white sugar [10].

Multivariate analysis (e.g., principal component analysis, PCA; hierarchical cluster analysis, HCA; linear discriminate analysis, LDA) were previously very often used to evaluate and/or classify honey in relation to its chemical composition, physicochemical or biological properties. Numerous papers have confirmed the suitability of this method for honey evaluation. $[2,3,6-8,18]$.

The antioxidant activity of honey depends on the botanical origin, which also determines its physicochemical properties. This study had two main objectives: (1) to evaluate and compare the physicochemical properties and antioxidant activity of five Polish blossom and multifloral honeys; (2) to identify/investigate potential relationships between the antioxidant properties of the honeys and their colour parameters and content of macroand micro-elements using principal component analysis (PCA).

\section{Materials and Methods}

\subsection{Sampling}

The study was conducted on 63 honeys harvested in south-eastern Poland (Lublin region) in 2019. The percentage of the predominant pollen grains in the honey samples was determined according to the method recommended by Polish law concerning analytical methods used in the assessment of honey [19]. The following types of honey were distinguished: rapeseed, RS (Brassica napus L., $n=10$ ), buckwheat, BW (Fagopyrum esculentum Moench, $n=8$ ), linden, LI (Tilia spp. L., $n=13$ ), black locust, AC (Robinia pseudoacacia L., $n=5$ ), and multifloral, MF (no dominant pollen, $n=27$ ). The honeys were purchased directly from beekeepers and stored in the dark at room temperature $20-25^{\circ} \mathrm{C}$.

\subsection{Analyses}

\subsubsection{Physicochemical Properties}

Water content was determined with a refractometer (Abbe Carl Zeiss, Jena, Germany) based on the refractive index of the honey in its liquid state. Water percentage by weight $(\% \mathrm{~m} / \mathrm{m})$ was read from the table as corresponding to the refractive index [20]. The content of reducing sugars and sucrose was determined by the Lane-Eynon method, according to the Polish Committee for Standardization (PN-88/A-77626. Bee honey).

The electrical conductivity $\left(\mathrm{mS} \mathrm{cm}^{-1}\right)$ and $\mathrm{pH}$ of the honey were determined according to [20] using a pIONneer 65 Meter (Radiometer Analytical, Villeurbanne, CEDEX-France) with a 4-pole conductivity cell (CDC 30T) and a combined pH electrode (E16M340). The free acidity of the honey was measured by potentiometric titration using a $0.1 \mathrm{M} \mathrm{NaOH}$ 
solution to obtain $\mathrm{pH} 8.30$ and the result was expressed in milliequivalents per kilogram of honey $\left(\mathrm{mval} \mathrm{kg}^{-1}\right)$.

The water activity $(\mathrm{aW})$ of fresh honey was performed using a Rotronic HygroLab C1 analyser (Bassersdorf, Switzerland) equipped with two HC2-AW measurement heads. Duplicate measurements were taken in the AWQ mode with stabilization set to $15 \mathrm{~min}$ after previously conditioning the honey samples at room temperature $\left(20 \pm 1{ }^{\circ} \mathrm{C}\right)$.

The concentration of 5-HMF (5-(hydroxymethyl-)furan-2-carbaldehyde) in $\mathrm{mg} \mathrm{kg}^{-1}$ was determined according to [21]. The absorbance of a clear solution of honey with water relative to a solution of honey with sodium bisulphate was measured at wavelengths 284 and $336 \mathrm{~nm}$. The measurement was made with a Carry 300 Bio spectrophotometer (Varian Australia Pty, Ltd., Mulgrave, Australia).

Diastase activity (diastase number DN, in Schade units per gram of honey) was determined by photometry using Phadebas tablets (Honey Diastase Test, Magle AB, Lund, Sweden). They contained non-soluble starch conjugated with a blue pigment and hydrolysed by the amylase present in the sample. The resulting water-soluble fragments of the starch chain were dyed blue. The absorbance of the coloured solution was measured with a Varian Carry 300 Bio spectrophotometer (Varian Australia PTY, Ltd.) at $620 \mathrm{~nm}$ [20].

The honey's colour was measured according to the procedure of [15] with some modifications. Briefly, the colour of three aliquots of each honey sample (previously equilibrated to room temperature) was measured three times in a round optical glass cell CR-A504 (diameter $34 \mathrm{~mm}$ ) using a portable CM-600d spectrophotometer (Konica Minolta Sensing, Inc., Osaka, Japan) equipped with cell holder CM-A515. The thickness of the honey layer was $20 \mathrm{~mm}$. Samples of multifloral, rapeseed, buckwheat and linden honey were crystallized naturally (set honey), and the black locust samples were in liquid form (strained honey). The results of the measurements (illuminant D65, observer $10^{\circ}$ ) were given in the CIE $\mathrm{L}^{*} \mathrm{a}^{*} \mathrm{~b}^{*}$ colour space, including the following spectral values: $\mathrm{L}^{*}$ (lightness axis), $\mathrm{a}^{*}$ (red to green axis), $\mathrm{b}^{*}$ (yellow to blue axis), $\mathrm{C}^{*}$ (saturation) and $\mathrm{h}^{\circ}$ (hue angle/tint).

For mineral analysis, samples were prepared for mineralization as follows: a $6 \mathrm{~mL}$ volume of $65 \%$ nitric acid (Suprapur grade; Merck, Germany) was poured over honey samples weighed out to within $0.0001 \mathrm{~g}$ and the certified reference material NCS ZC 73014 Tea (to verify the method) in vessels (PFA). All solutions together with a blank sample were mineralized in a MARSXpress 5 microwave digester (CEM Corporation, Matthews, NC, USA). The oven was programmed for mineralization of the samples as follows: power- $1600 \mathrm{~W} / 100 \%$ max power; temperature increment-20 $\mathrm{min} / 200{ }^{\circ} \mathrm{C}$; holding time $-20 \mathrm{~min}$. Then the mineralized samples were transferred to volumetric flasks using ultrapure water produced in an HLP 20UV demineralizer (HYDROLAB, Poland). Schinkel buffer (enth./ cont. $10 \mathrm{~g} \mathrm{~L}^{-1} \mathrm{CsCl}+100 \mathrm{~g} \mathrm{~L}^{-1}$ La; Merck, Germany) was used to minimize interference during analysis $(\mathrm{Mg}, \mathrm{K}$ and $\mathrm{Na})$.

$\mathrm{K}, \mathrm{Na}, \mathrm{Mg}, \mathrm{Zn}, \mathrm{Fe}, \mathrm{Mn}$, and $\mathrm{Cu}$ were determined according to the procedure of [3] using a Varian AA240FS spectrometer (Fast Sequential Atomic Absorption Spectrometer, Varian Australia Pty Ltd., Mulgrave, Australia). The elements were atomized in the flame of a burner fed with a mixture of air (oxidizing gas, flow $13 \mathrm{~L} \mathrm{~min}^{-1}$ ) and acetylene (combustible gas, flow $2.0 \mathrm{~L} \mathrm{~min}^{-1}$ ). The following parameters were used: instrument mode-absorbance; measurement mode-integration; calibration mode-concentration; calibration algorithm-New Rational. Analytical wavelengths (nm): Mg 285.2, Zn 213.9, Fe 248.3, Mn 279.5, Cu 324.7, Na 589.0, and K 766.5. Background correction was used in the determination of $\mathrm{Mg}, \mathrm{Zn}, \mathrm{Fe}, \mathrm{Mn}$ and $\mathrm{Cu}$. To plot a standard curve, single-element standard solutions (Merck, Germany) were used for each element $(\mathrm{K}, \mathrm{Na}, \mathrm{Mg}, \mathrm{Zn}, \mathrm{Cu}$, Fe and $\mathrm{Mn}$ ) with a mass concentration of $1000 \mathrm{mg} \mathrm{L}^{-1}$. The following limits of detection (LOD) were used in the analysis: $0.01 \mathrm{mg} \mathrm{kg}^{-1}$ for $\mathrm{Na}, \mathrm{Zn}, \mathrm{Mn}$ and $\mathrm{Cu} ; 0.04 \mathrm{mg} \mathrm{kg}^{-1}$ for K ; $0.09 \mathrm{mg} \mathrm{kg}^{-1}$ for Fe; and $0.47 \mathrm{mg} \mathrm{kg}^{-1}$ for $\mathrm{Mg}$. 


\subsubsection{Antioxidant Activity}

The capacity of the honeys to scavenge the stable free radical 2,2-diphenyl-1picrylhydrazyl (DPPH, Sigma Aldrich Co., St. Louis, MO, USA) was tested according to the method of [22]. Samples of the honeys $(2 \mathrm{~g})$ were dissolved in $10 \mathrm{~mL}$ of distilled water (HLP 20UV, HYDROLAB, Straszyn, Poland), then an aliquot $(0.2 \mathrm{~mL})$ of each dilution was mixed with a $1.8 \mathrm{~mL}$ solution of $0.1 \mathrm{mM}$ DPPH in methanol (Sigma Aldrich Co., St. Louis, MO, USA). The reaction mixture was left in the dark at room temperature for $60 \mathrm{~min}$. Next, the absorbance of the mixture was measured spectrophotometrically (UV-2600i spectrophotometer, Shimadzu, Japan) at $517 \mathrm{~nm}$ against methanol as a blank. All the determinations were performed in triplicates. The calibration curve was plotted in a range from 0.1 to $100 \mu \mathrm{g} \mathrm{mL}{ }^{-1}$ of Trolox (Sigma-Aldrich, Co., St. Louis, MO, USA) solution in ethanol. The results were expressed as $\mathrm{mM}$ of Trolox equivalent (TE) per $1 \mathrm{~kg}$ of honey (mM TE kg ${ }^{-1}$ honey).

The total ferric reducing antioxidant power assay (FRAP assay) was performed according to [23]. FRAP reagent was prepared by mixing $25 \mathrm{~mL}$ of $0.3 \mathrm{M}$ acetate buffer ( $\mathrm{pH}$ 3.6) with a $2.5 \mathrm{~mL}$ solution of $10 \mathrm{mM}$ TPTZ (Sigma Aldrich Co, St. Louis, MO, USA) in $40 \mathrm{mM}$ $\mathrm{HCl}$, and $2.5 \mathrm{~mL}$ of $20 \mathrm{mM}$ ferric chloride (Sigma Aldrich Co, USA). An aliquot (0.2 mL) of each honey dilution $(1 \mathrm{~g}$ in $10 \mathrm{~mL}$ distilled water) was mixed with $1.8 \mathrm{~mL}$ of FRAP reagent. The resulting mixture was then pre-warmed at $37^{\circ} \mathrm{C}$ for $10 \mathrm{~min}$. The absorbance was measured spectrophotometrically (UV-2600i spectrophotometer, Shimadzu, Japan) at $593 \mathrm{~nm}$ against a blank that was prepared with distilled water. All the determinations were performed in triplicates. A calibration curve was prepared using the ethanol solution of Trolox (Sigma Aldrich Co., St. Louis, MO, USA) in a range from 25 to $300 \mathrm{nmol} \mathrm{mL}{ }^{-1}$. FRAP values were expressed as $\mathrm{mM}$ of Trolox equivalent per $\mathrm{kg}$ of honey $\left(\mathrm{mM} \mathrm{TE} \mathrm{kg}^{-1}\right)$.

\subsection{Statistical Analysis}

Statistical analysis of the results was performed in Statistica ver. 13 (TIBCO Software Inc., Palo Alto, CA, USA). One-way analysis of variance (ANOVA) followed by Tukey's (HSD) test was used to compare means of physicochemical traits and colour parameters between honey types (multifloral, rapeseed, buckwheat, linden and black locust). The normality and homogeneity of the variance of minerals were verified by the KolmogorovSmirnov test and Levene's F-test, respectively. The influence of the honey type on the elemental concentrations was verified by the Kruskal-Wallis test (comparison of multiple independent groups). Differences between means at confidence levels of $95 \%$ and $99 \%$ $(p<0.05$ and $p<0.01$, respectively) were considered statistically significant. The mean and standard deviation are presented in the tables. The relationship between parameters of antioxidant activity (FRAP and DPPH) and physicochemical traits and mineral contents in the honeys was determined by calculating Pearson's correlation coefficients (r) and Spearman's rank correlation coefficients (rS), respectively. The correlations were further verified by principal component analysis (PCA), separately for two data sets (for antioxidant activity and colour and for antioxidant activity and minerals) to demonstrate the diversity among honey types.

\section{Results and Discussion}

\subsection{Physicochemical Properties}

The honey type significantly influenced most of its physicochemical parameters (except the content of water, saccharose and reducing sugars), all colour parameters, and the concentrations of $\mathrm{K}, \mathrm{Mn}$ and $\mathrm{Cu}$ (Table 1).

Although the water content in the honeys did not differ significantly, the value of this parameter indicates the maturity of the honey (readiness for harvest). The mean water content was similar, ranging from $17.11 \%$ in the linden honey to $17.93 \%$ in the rapeseed honey, and thus did not exceed the maximum acceptable content of $20 \%$ [14]. Sugars make up the largest proportion of dry matter in honey, and their qualitative and quantitative composition is an important criterion in the quality assessment of honey. The 
most important factors for determining the sugar composition of honey include the region of origin, climate conditions, and types of flowers used by the bees [24]. In the present study, the highest content of reducing sugars and the lowest content of saccharose was noted in the black locust honey $(77.24 \%$ and $1.83 \%)$, while the reverse pattern was noted in the linden honey $(73.76 \%$ and $2.14 \%)$. It should be stressed that the saccharose content in the honey did not exceed the acceptable limit of $5 \mathrm{~g} / 100 \mathrm{~g}$ of product.

Table 1. Parameters of physicochemical traits and antioxidant activity of the honey types (mean values \pm standard deviation).

\begin{tabular}{|c|c|c|c|c|c|}
\hline Parameters & Multifloral (MF) & Rapeseed (RS) & Buckwheat (BW) & Linden (LI) & Black Locust (AC) \\
\hline Water (\%) & $17.53 \pm 1.01^{\mathrm{a}}$ & $17.93 \pm 0.89^{a}$ & $17.83 \pm 1.17^{\mathrm{a}}$ & $17.11 \pm 1.23^{\mathrm{a}}$ & $17.90 \pm 0.58^{a}$ \\
\hline Reducing sugars (\%) & $74.12 \pm 3.18^{a}$ & $74.60 \pm 1.40^{\mathrm{a}}$ & $74.93 \pm 2.42^{\mathrm{a}}$ & $73.76 \pm 2.39^{a}$ & $77.24 \pm 1.00^{\mathrm{a}}$ \\
\hline Sucrose $(\%)$ & $2.09 \pm 0.28^{\mathrm{a}}$ & $2.04 \pm 0.13^{\mathrm{a}}$ & $2.02 \pm 0.22^{\mathrm{a}}$ & $2.14 \pm 0.23^{\mathrm{a}}$ & $1.83 \pm 0.09^{\mathrm{a}}$ \\
\hline $\mathrm{pH}$ & $3.80 \pm 0.15^{\mathrm{a}}$ & $3.83 \pm 0.10^{\mathrm{a}}$ & $3.69 \pm 0.17^{\mathrm{a}}$ & $3.91 \pm 0.16^{b}$ & $3.68 \pm 0.12^{\mathrm{a}}$ \\
\hline Free acidity $\left(\mathrm{mval} \mathrm{kg}^{-1}\right)$ & $32.1 \pm 9.9^{\mathrm{AB}}$ & $21.9 \pm 4.2^{\mathrm{A}}$ & $44.5 \pm 2.6^{\mathrm{C}}$ & $35.1 \pm 9.9^{B C}$ & $29.1 \pm 10.3^{\mathrm{AB}}$ \\
\hline $\begin{array}{l}\text { Electrical conductivity } \\
\left(\mathrm{mS} \mathrm{cm}^{-1}\right)\end{array}$ & $0.390 \pm 0.145^{\mathrm{AB}}$ & $0.232 \pm 0.037^{\mathrm{A}}$ & $0.448 \pm 0.099 \mathrm{AB}$ & $0.564 \pm 0.163^{B}$ & $0.304 \pm 0.149^{\mathrm{AB}}$ \\
\hline$a_{W}$ & $0.567 \pm 0.026^{\mathrm{AB}}$ & $0.582 \pm 0.017^{\mathrm{B}}$ & $0.570 \pm 0.017^{\mathrm{AB}}$ & $0.546 \pm 0.023^{\mathrm{A}}$ & $0.552 \pm 0.028^{\mathrm{AB}}$ \\
\hline 5-HMF $\left(\mathrm{mg} \mathrm{kg}^{-1}\right)$ & $5.50 \pm 2.77^{\mathrm{A}}$ & $3.67 \pm 3.81^{\mathrm{A}}$ & $14.51 \pm 8.54^{\mathrm{B}}$ & $3.49 \pm 2.27^{\mathrm{A}}$ & $4.20 \pm 1.69^{\mathrm{A}}$ \\
\hline $\begin{array}{c}\text { Diastase number (Schade unit) } \\
\text { Colour CIE }\end{array}$ & \multicolumn{4}{|c|}{ Colour CIE } & $21.45 \pm 4.86^{\mathrm{A}}$ \\
\hline $\mathrm{L}^{*}$ & $44.12 \pm 7.28^{C}$ & $49.47 \pm 6.60^{\mathrm{D}}$ & $30.84 \pm 2.44^{\mathrm{A}}$ & $35.64 \pm 3.54^{\text {B }}$ & $31.55 \pm 5.42 \mathrm{AB}$ \\
\hline$a^{*}$ & $2.36 \pm 1.48^{\mathrm{B}}$ & $0.90 \pm 0.36^{\mathrm{A}}$ & $3.22 \pm 0.92^{C}$ & $0.88 \pm 0.51^{\mathrm{A}}$ & $0.61 \pm 0.28^{\mathrm{A}}$ \\
\hline$b^{*}$ & $16.05 \pm 5.84^{\mathrm{B}}$ & $13.29 \pm 2.03^{\mathrm{B}}$ & $6.91 \pm 2.90^{\mathrm{A}}$ & $8.74 \pm 2.38^{\mathrm{A}}$ & $5.09 \pm 2.40^{\mathrm{A}}$ \\
\hline$C^{*}$ & $16.25 \pm 5.96^{\mathrm{B}}$ & $13.08 \pm 2.27^{\mathrm{B}}$ & $7.64 \pm 2.93^{\mathrm{A}}$ & $8.86 \pm 2.36^{\mathrm{A}}$ & $5.14 \pm 2.39^{\mathrm{A}}$ \\
\hline$h^{\circ}$ & $81.97 \pm 3.45^{\text {B }}$ & $85.94 \pm 1.39^{\mathrm{C}}$ & $62.70 \pm 6.96^{\mathrm{A}}$ & $84.40 \pm 3.62^{\mathrm{BC}}$ & $82.38 \pm 4.17^{\text {В }}$ \\
\hline \multicolumn{6}{|l|}{ Minerals (mg kg${ }^{-1}$ ) } \\
\hline K & $1055.55 \pm 479.47^{\mathrm{ab}}$ & $700.94 \pm 399.30^{a}$ & $1155.26 \pm 359.17^{a b}$ & $1258.27 \pm 564.50^{b}$ & $876.26 \pm 435.06^{a b}$ \\
\hline $\mathrm{Na}$ & $29.10 \pm 20.03^{a}$ & $24.21 \pm 12.72^{\mathrm{a}}$ & $33.18 \pm 29.98^{a}$ & $25.86 \pm 14.65^{\mathrm{a}}$ & $15.09 \pm 1.16^{\mathrm{a}}$ \\
\hline $\mathrm{Mg}$ & $28.77 \pm 10.55^{\mathrm{a}}$ & $20.15 \pm 4.26^{\mathrm{a}}$ & $29.56 \pm 10.36^{a}$ & $27.93 \pm 9.83^{a}$ & $23.19 \pm 9.94^{\mathrm{a}}$ \\
\hline $\mathrm{Zn}$ & $1.84 \pm 1.80^{\mathrm{a}}$ & $1.26 \pm 0.69^{a}$ & $2.94 \pm 3.03^{\mathrm{a}}$ & $1.65 \pm 0.97^{\mathrm{a}}$ & $0.88 \pm 0.31^{\mathrm{a}}$ \\
\hline $\mathrm{Fe}$ & $1.66 \pm 0.68^{\mathrm{a}}$ & $1.26 \pm 0.49^{\mathrm{a}}$ & $1.85 \pm 0.92^{\mathrm{a}}$ & $1.71 \pm 0.62^{\mathrm{a}}$ & $1.39 \pm 0.97^{\mathrm{a}}$ \\
\hline Mn & $1.77 \pm 1.56^{\mathrm{ab}}$ & $1.37 \pm 1.50^{\mathrm{ab}}$ & $5.58 \pm 4.29^{b}$ & $1.22 \pm 1.36^{\mathrm{ab}}$ & $0.72 \pm 0.62^{\mathrm{a}}$ \\
\hline $\mathrm{Cu}$ & $0.56 \pm 0.16^{\mathrm{AB}}$ & $0.48 \pm 0.17^{\mathrm{A}}$ & $0.95 \pm 0.37^{\mathrm{B}}$ & $0.52 \pm 0.09 \mathrm{AB}$ & $0.47 \pm 0.07^{\mathrm{A}}$ \\
\hline \multicolumn{6}{|l|}{ Antioxidant activity } \\
\hline $\mathrm{DPPH}\left(\mathrm{mM} \mathrm{TE} \mathrm{kg}{ }^{-1}\right)$ & $1.12 \pm 0.44^{\mathrm{BC}}$ & $0.83 \pm 0.12^{\mathrm{A}}$ & $2.33 \pm 0.36^{\mathrm{C}}$ & $0.90 \pm 0.16^{\mathrm{AB}}$ & $0.63 \pm 0.17^{\mathrm{A}}$ \\
\hline FRAP (mM TE kg $\left.{ }^{-1}\right)$ & $1.28 \pm 0.49^{\mathrm{B}}$ & $0.47 \pm 0.10^{\mathrm{A}}$ & $2.14 \pm 0.27^{C}$ & $0.53 \pm 0.15^{\mathrm{A}}$ & $0.29 \pm 0.01 \mathrm{~A}$ \\
\hline
\end{tabular}

$\mathrm{a}_{\mathrm{W}}$, water activity; 5-HMF, 5-(hydroxymethyl-)furan-2-carbaldehyde; $\mathrm{L}^{*}$, lightness; $\mathrm{a}^{*}$, redness; $\mathrm{b}^{*}$, yellowness; $\mathrm{C}^{*}$, saturation; $\mathrm{h}^{\circ}$, hue angle; $\mathrm{K}$, potassium; $\mathrm{Na}$, sodium; $\mathrm{Mg}$, magnesium; Fe, iron; $\mathrm{Zn}$, zinc; $\mathrm{Mn}$, manganese; $\mathrm{Cu}$, copper; DPPH, scavenging capacity; FRAP, ferric reducing antioxidant power. Means with different letters in rows differ significantly according to Tukey's test: ${ }^{\text {a }},{ }^{\mathrm{b}}-p<0.05 ;{ }^{\mathrm{A}}, \mathrm{B} \_p<0.01$.

All the honeys had a $\mathrm{pH}<4$. Although regulations do not specify the $\mathrm{pH}$ of honey, it is worth noting that honey $\mathrm{pH}$ between 3.2 and 4.5 , together with titratable acidity, inhibits the growth of microbes [4]. The higher range of $\mathrm{pH}$ for the same honey types in this study (from various regions of Poland), i.e., from 4.07 (buckwheat) to 4.23 (linden) was reported earlier [6]. Lower $\mathrm{pH}$ than in the present study was reported for Indian blossom honey (3.5) [7], while higher $\mathrm{pH}$ (4.38) was found in Slovakian honey [25].

The honey type significantly influenced its degree of acidity, which ranged from $21.9 \mathrm{mval} \mathrm{kg}^{-1}$ (rapeseed) to $44.5 \mathrm{mval} \mathrm{kg}^{-1}$ (buckwheat), without exceeding the limit in EU regulations [14], which is 50 mequivalents acid per $\mathrm{kg}$. Acidity results mainly from the presence of organic acids, amino acids and phenolic acids in honey, as well as from processes taking place during its maturation [13]. Free acidity has been shown to remain practically constant in honey, but with an increase observed during storage for 20 months at room temperature [26] or frozen storage for 18 months [15].

Specific conductivity is a parameter that can be used to determine the botanical origin of honey, i.e., to distinguish nectar honey (up to $0.8 \mathrm{mS} \mathrm{cm}^{-1}$ ) from honeydew honey (over $0.8 \mathrm{mS} \mathrm{cm}^{-1}$ ). This was also confirmed in the present study, as the specific conductivity of the nectar honeys varied significantly $(p<0.01)$ from $0.232 \mathrm{mS} \mathrm{cm}^{-1}$ (rapeseed) to $0.564 \mathrm{mS} \mathrm{cm}^{-1}$ (linden). The specific conductivity of Slovakian honey averaged 
$0.6515 \mathrm{mS} \mathrm{cm}^{-1}$, ranging from 0.1345 to $0.9912 \mathrm{mS} \mathrm{cm}^{-1}$ [25]. Multifloral and acacia honeys from India exhibited lower conductivity $\left(0.25-0.26 \mathrm{mS} \mathrm{cm}^{-1}\right)$ [7].

The aW of honey is usually between 0.50 and 0.65 , and in the literature, aW values above 0.60 are considered to represent a critical threshold for microbial stability [4] due to the activity of various species of bacteria and osmophilic yeasts resulting in fermentation [12]. In the present study, the honeys did not exceed the critical value for this parameter, but it varied significantly $(p<0.01$ ) from 0.546 (linden honey) to 0.582 (rapeseed honey). These honey types also had the lowest $(17.11 \%)$ and highest $(17.93 \%)$ water content, which indicates a linear relationship between the two parameters, statistically confirmed in the present study $(r=0.616, p=0.000)$. Nonetheless, due to the significant influence of temperature, honey type (flower or honeydew), harvesting year, geographical and botanical origin, a universal linear equation for water activity and moisture content could not be established [27]. The wider range of water activity in honeys $(0.456 \leq \mathrm{aW} \leq 0.659)$ was linked to the varied composition of sugars [25]. Water activity in honey from India ranged from 0.507 to 0.566 [7], and in flower honey from Turkey was between 0.51 and 0.69 [24]. Low water activity $(\mathrm{aW})$ together with low $\mathrm{pH}$, low protein content, and high osmotic pressure has an inhibitory effect on the development of bacteria [13].

An important indicator of the quality and health safety of honey is the content of 5-hydroxymethylfurfural (5-HMF). The values for this parameter in the present study were low, well under the limit of $40 \mathrm{mg} \mathrm{kg}^{-1}$ [14]. Significantly $(p<0.01)$ the highest content of $5-\mathrm{HMF}$ was noted in the buckwheat honey (14.51 mg kg-1); it was more than four times as high as in the linden $\left(3.49 \mathrm{mg} \mathrm{kg}^{-1}\right)$ and rapeseed $\left(3.67 \mathrm{mg} \mathrm{kg}^{-1}\right)$ honeys $(p<0.01)$. The 5 -HMF content between 0 and $4.12 \mathrm{mg} \mathrm{kg}^{-1}$ was reported for Turkish flower honey [24], which was considered fresh honey. Higher 5-HMF content was found in Slovakian honeys $25.76 \mathrm{mg} \mathrm{kg}^{-1}$ [25], while the level in Indian honeys ranged from $5.49 \mathrm{mg} \mathrm{kg}^{-1}$ in acacia honey to $22.64 \mathrm{mg} \mathrm{kg}^{-1}$ in multifloral honey [7]. For Andalusian multifloral honey, the content of 5-HMF was found between 0.19 and $41.16 \mathrm{mg} \mathrm{kg}^{-1}$ [28].

The diastase number (DN) indicates the amylolytic activity of honey. Alpha-amylase (diastase) is an enzyme that takes part in the hydrolytic degradation of complex sugars. Like 5-HMF, the diastatic activity of honey can be used as an indicator of adulteration, ageing, overheating (increased temperature), and the degree of preservation [16]. All honey types tested in the present study had a diastase number $>8$, i.e., above the recommended minimum [14]. DN values obtained for Polish regional honeys [29] confirmed the low enzymatic activity of rapeseed $(15.32 \mathrm{DN})$ and higher activity in multifloral $(22.15 \mathrm{DN})$ and linden (31.99 DN) honey. In turn, the diastase number of polyfloral honeys from Andalusia varied widely from 6.05 to 40.89 [28].

The honey type significantly $(p<0.01)$ influenced all parameters in the instrumental assessment of colour (Table 1). The highest lightness value was noted for the rapeseed honey $\left(L^{*}=49.47\right)$, followed by the multifloral honey $\left(L^{*}=44.12\right)$, while the darkest was black locust honey $\left(L^{*}=31.55\right)$ and buckwheat honey $\left(L^{*}=30.84\right)$. Buckwheat honey also had the highest value for the colour red $\left(\mathrm{a}^{*}=3.22\right)$ and the lowest hue angle $\left(\mathrm{h}^{\circ}=62.70\right)$. The hue angle in the other honey types ranged from $\mathrm{h}^{\circ}=81.97$ (multifloral) to $\mathrm{h}^{\circ}=85.94$ (rapeseed). Hue angle is defined as starting at the $+\mathrm{a}^{*}$ axis and is expressed in degrees: $0^{\circ}$ is red $\left(+\mathrm{a}^{*}\right), 90^{\circ}$ is yellow $\left(+\mathrm{b}^{*}\right), 180^{\circ}$ is green $\left(-\mathrm{a}^{*}\right)$, and $270^{\circ}$ is blue $\left(-\mathrm{b}^{*}\right)$. Values between $0^{\circ}$ and $90^{\circ}$ are a mixture of red and yellow, resulting in an orange colour.

The amount of red was similar for the black locust, linden and rapeseed honeys $\left(0.61 \leq \mathrm{a}^{*} \leq 0.90\right)$, in contrast to the multifloral honey $\left(\mathrm{a}^{*}=2.36\right)$ and the aforementioned buckwheat honey $\left(a^{*}=3.22\right)$. In the case of the colour yellow and saturation, the varieties can be divided into two groups with similar values for these parameters, i.e., black locust, buckwheat and linden $\left(5.09 \leq \mathrm{b}^{*} \leq 8.74\right.$ and $\left.5.14 \leq \mathrm{C}^{*} \leq 8.86\right)$ vs. rapeseed and multifloral $\left(13.29 \leq \mathrm{b}^{*} \leq 16.05\right.$ and $\left.13.08 \leq \mathrm{C}^{*} \leq 16.25\right)$.

A wider range of values for colour components for Polish honey was reported earlier [6], respectively: $26 \leq \mathrm{L}^{*} \leq 51 ;-3.41 \leq \mathrm{a}^{*} \leq 7.9$; and $5.8 \leq \mathrm{b}^{*} \leq 23.7$. The differences may have been due to differences in the preparation of samples, which were heated 
and homogenized prior to analysis. Nectar contains natural plant pigments such as carotenoids, anthocyanins, flavonoids, and chlorophyll, which determine the colour of the honey through various amounts of colours, including yellow, red, brown and green. The colour of the product is also influenced by honey colloids, polyphenols (e.g., tannins), and melanoidins. Phenolic compounds function not only as pigments but also as antioxidants, insecticides and fungicides [6]. The colour of honey is also largely determined by its degree of crystallization and the conditions in which physicochemical changes take place during storage.

In the present study, the dark buckwheat honey $\left(\mathrm{L}^{*}=30.84\right)$ had a high free acid value $\left(44.5 \mathrm{mval} \mathrm{kg}^{-1}\right)$, while the light rapeseed honey $\left(\mathrm{L}^{*}=49.47\right)$ had significantly $(p<0.01)$ the lowest acidity $\left(21.9 \mathrm{mval} \mathrm{kg}^{-1}\right)$. Dark honeys have been shown to have much higher acidity than light ones [9]. Kaczmarek et al. [6] also reported higher levels of free acids in buckwheat (34.25 meq kg ${ }^{-1}$ ), multifloral (34.04 meq kg ${ }^{-1}$ ) and linden (31.09 $\mathrm{meq} \mathrm{kg}^{-1}$ ) honey than in acacia (12.8 meq $\left.\mathrm{kg}^{-1}\right)$ and rapeseed $\left(10.5 \mathrm{meq} \mathrm{kg}^{-1}\right)$ honey.

In the present study, the highest content of elements was generally found in the buckwheat honey and the lowest in the black locust and rapeseed honey (Table 1). The type significantly influenced the content of $\mathrm{Mn}$ and $\mathrm{Cu}(p<0.01)$ and $\mathrm{K}(p<0.05)$. The highest content of potassium was noted in the linden honey $\left(1258.3 \mathrm{mg} \mathrm{kg}^{-1}\right)$ and the lowest in the rapeseed honey $\left(700.9 \mathrm{mg} \mathrm{kg}^{-1}\right)$. The potassium content in the honey varieties was similar to that obtained in honey from Poland (892.4 $\left.\mathrm{mg} \mathrm{kg}^{-1}\right)$ [3] and Malaysia $\left(904.9 \mathrm{mg} \mathrm{kg}^{-1}\right)$ [30], but lower than in Hungarian honey (397.88 $\left.\mathrm{mg} \mathrm{kg}^{-1}\right)$ [31].

The buckwheat honey had significantly the highest content of $\mathrm{Mn}$ and $\mathrm{Cu}$ (5.58 and $\left.0.95 \mathrm{mg} \mathrm{kg}^{-1}\right)$. The black locust honey had the lowest level of manganese $\left(0.72 \mathrm{mg} \mathrm{kg}^{-1}\right)$, and the black locust and rapeseed honeys had the lowest content of copper (0.47-0.48 $\left.\mathrm{mg} \mathrm{kg}^{-1}\right)$. Wieczorek et al. [32] reported lower values for $\mathrm{K}\left(233-782 \mathrm{mg} \mathrm{kg}^{-1}\right)$, $\mathrm{Mg}\left(11.6-24 \mathrm{mg} \mathrm{kg}^{-1}\right)$, Mn (0.37-1.25 mg kg-1), and $\mathrm{Cu}\left(0.04-0.06 \mathrm{mg} \mathrm{kg}^{-1}\right)$ in multifloral, linden and black locust honeys, but higher values for $\mathrm{Zn}\left(1.65-6.20 \mathrm{mg} \mathrm{kg}^{-1}\right)$ and Fe (1.9-4.0 mg kg-1) compared to the results of our study, which in turn were in agreement with those obtained by other authors [33] for varietal honeys from Podkarpacie in Poland. They noted the highest content of $\mathrm{Zn}, \mathrm{Mn}$ and $\mathrm{Cu}$ in buckwheat honey, in comparison with linden, rapeseed and multifloral honeys. Our previous research [3] also indicated a higher concentration of these elements in buckwheat honey. For this reason, Deng et al. [34] suggest that the levels of $\mathrm{Mn}, \mathrm{Zn}$ and $\mathrm{Cu}$ in buckwheat honey can potentially be used to distinguish this variety of honey. Many authors also stressed that dark honeys have higher mineral content than light ones [23,30], as well as a stronger flavour [34] and higher content of phenolic compounds, which influence antioxidant activity [7].

\subsection{Antioxidant Activity}

The buckwheat honey had the highest content of elements considered to be antioxidants $(\mathrm{Zn}, \mathrm{Mn}$ and $\mathrm{Cu}$ ). This is also indicated by the results for antioxidant activity measured in the reaction with DPPH and by the FRAP value (Table 1). Significantly $(p<0.01)$ the highest antioxidant activity was noted in the buckwheat honey (DPPH $2.33 \mathrm{mM} \mathrm{TE} \mathrm{kg}^{-1}$ and FRAP $2.14 \mathrm{mM} \mathrm{TE} \mathrm{kg}{ }^{-1}$ ), and the lowest activity in the black locust (DPPH $0.63 \mathrm{mM} \mathrm{TE} \mathrm{kg}{ }^{-1}$ and FRAP $0.29 \mathrm{mM} \mathrm{TE} \mathrm{kg}^{-1}$ ), rapeseed (DPPH $0.83 \mathrm{mM}$ TE $\mathrm{kg}^{-1}$ and FRAP $0.47 \mathrm{mM} \mathrm{TE} \mathrm{kg}^{-1}$ ) and linden (DPPH $0.90 \mathrm{mM} \mathrm{TE} \mathrm{kg}{ }^{-1}$ and FRAP $0.53 \mathrm{mM} \mathrm{TE} \mathrm{kg}^{-1}$ ) honeys.

The highest antioxidant activity in buckwheat honey from Poland measured in reactions with DPPH and ABTS and the lowest in rapeseed and acacia honeys were reported previously [11]. In the present study, the mean DPPH values in $\mathrm{mM} \mathrm{TE} \mathrm{kg}{ }^{-1}$ in the rapeseed, buckwheat, linden and black locust honeys were about twice as high as those reported earlier [2]. Škrovánková et al. [35] analysed total antioxidant capacity (TAC) using the DPPH reagent and found that it was highest in honeydew honey, followed by multifloral, forest, and floral honeys, with the lowest values noted in rape and acacia honeys. The DPPH activity in buckwheat honey from China was $0.304 \mathrm{mg}$ Trolox $/ \mathrm{g}$, and the FRAP 
value was $0.355 \mathrm{mg}$ Trolox/g [36]. However, it may be difficult to compare our results for antioxidant activity with values reported by other authors due to the differences in their analysis or presentation. Nevertheless, it should be emphasized that many studies indicate that dark honeys show higher activity than light honeys. Piszcz and Głód [37], based on the assessment of total antioxidant potential (TAP), reported the following order for varietal honeys: buckwheat $>$ honeydew $>$ linden $>$ multifloral $>$ acacia. Dżugan et al. [38] found the highest antioxidant activity (DPPH) in buckwheat honey $(82.41 \%)$ and the lowest in rapeseed honey $(21.81 \%)$. Other authors [10] also confirmed high antioxidant activity in buckwheat honey (17.0 mmol Trolox/g) compared to soybean, sweet clover, fireweed, and acacia honeys $(8.3,6.1,3.1$ and $3.0 \mathrm{mmol}$ Trolox/g).

\subsection{Correlations}

To test the relationships between antioxidant capacity expressed as DPPH and FRAP and physicochemical properties, colour parameters, and concentrations of selected elements, Pearson (r) or Spearman (rS) correlations were calculated. In the case of the first group of properties, DPPH and FRAP were shown to be significantly $(p<0.001)$ and positively correlated with 5-HMF $(r=0.643$ and $r=0.676)$, diastase number $(r=0.612$ and $\mathrm{r}=0.706)$, and free acids $(\mathrm{r}=0.544$ and $\mathrm{r}=0.560)$. The only significant negative correlation was between DPPH and $\mathrm{pH}(\mathrm{r}=-0.320, p<0.05)$.

Antioxidant activity (DPPH and FRAP) was positively correlated with the colour red $(\mathrm{r}=0.452$ and $\mathrm{r}=0.549, p<0.001)$ and negatively with lightness $(\mathrm{r}=-0.309$ and $\mathrm{r}=-0.259$, $p<0.05)$ and hue $(r=-0.781$ and $r=-0.706, p<0.001)($ Table 2).

Table 2. Correlations between antioxidant activity and colour parameters and minerals.

\begin{tabular}{ccc}
\hline Parameter & FRAP & DPPH \\
\hline Colour CIE & Pearson's correlation coefficient $(\mathrm{r})$ \\
\hline $\mathrm{L}^{*}$ & $-0.259^{*}$ & $-0.309^{*}$ \\
$\mathrm{a}^{*}$ & $0.549^{* * *}$ & $0.452^{* * *}$ \\
$\mathrm{~b}^{*}$ & 0.022 & -0.127 \\
$\mathrm{C}^{*}$ & 0.058 & -0.091 \\
$\mathrm{~h}^{\circ}$ & $-0.706^{* * *}$ & $-0.781^{* * *}$ \\
\hline Minerals & Spearman's rank correlation coefficient $(\mathrm{rS})$ \\
\hline $\mathrm{K}$ & 0.155 & $0.268^{*}$ \\
$\mathrm{Na}$ & 0.173 & 0.176 \\
$\mathrm{Mg}$ & 0.156 & $0.276^{*}$ \\
$\mathrm{Fe}$ & 0.247 & 0.218 \\
$\mathrm{Zn}$ & 0.212 & 0.127 \\
$\mathrm{Cu}$ & $0.386^{* *}$ & $0.522^{* * *}$ \\
$\mathrm{Mn}$ & $0.370^{* *}$ & $0.457^{* * *}$ \\
\hline
\end{tabular}

${ }^{*} p<0.05 ;{ }^{* *} p<0.01 ; * * * p<0.001 ; \mathrm{L}^{*}$, lightness; $\mathrm{a}^{*}$, redness; $\mathrm{b}^{*}$, yellowness; $\mathrm{C}^{*}$, saturation; $\mathrm{h}^{\circ}$, hue angle; $\mathrm{K}$ potassium; $\mathrm{Na}$, sodium; $\mathrm{Mg}$, magnesium; $\mathrm{Fe}$, iron; $\mathrm{Zn}$, zinc; Mn, manganese; $\mathrm{Cu}$, copper; $\mathrm{DPPH}$, scavenging capacity; FRAP, ferric reducing antioxidant power.

Kuś et al. [2], for six Polish single-variety honeys, reported higher correlation coefficients for DPPH and FRAP with colour parameters: for $L^{*} r=-0.955$ and -0.961 , for $a^{*} r=0.943$ and 0.964 , and for $b^{*} r=0.814$ and 0.786 . Lower correlation coefficients for these parameters were obtained for honey from Slovenia [23]. The intensity of honey colour may be associated with its antioxidant capacity, as the content of phenols, flavonoids and carotenoids is greater in darker honeys than in lighter ones [5]. Moreover, the acceleration of the Maillard reaction or fructose caramelization can contribute to a darker colour of honey through the production of brown pigments, concomitantly with the formation of $\mathrm{HMF}$ as an intermediate product. Similar changes in rape honey, consisting in a reduction in lightness $\left(\mathrm{L}^{*}\right)$ but an increase in redness $\left(\mathrm{a}^{*}\right)$ and colour intensity (ABS450, mAU) were observed in our previous study [16], which can be directly linked to the presence of pigments such as terpenes, carotenoids, and some flavonoids [7]. 
High, positive correlation coefficients between colour evaluation $(\triangle \mathrm{A})$ and antioxidant capacity were previously reported for ABTS $r=0.8836$ and for DPPH $r=0.8937$ [35]. Many authors confirm a strongly positive and significant $(p<0.01)$ relationship between colour intensity, expressed as ABS450, and DPPH and FRAP. For instance, Moniruzzaman et al. [39] reported coefficients of $r=0.938$ and $r=0.873$, and Beretta et al. [40], reported $r=0.889$ and $r=0.933$. A lower correlation coefficient $(r=0.68)$ between ABS450 and DPPH was obtained by Kaczmarek et al. [6].

The DPPH and FRAP parameters characterizing antioxidant activity were most strongly and positively correlated with antioxidant minerals: $\mathrm{Cu}(\mathrm{rS}=0.522, p<0.001$ and $\mathrm{rS}=0.386, p<0.01)$ and $\mathrm{Mn}(\mathrm{rS}=0.457, p<0.001$ and $\mathrm{rS}=0.370, p<0.01)$ (Table 2).

To our knowledge, there are few reports on the correlation between the minerals content and antioxidant activity of honeys. In the present study, low and non-significant $(p>0.05)$ correlation coefficients were obtained for parameters of antioxidant activity and elements $\mathrm{Na}, \mathrm{Fe}$ and $\mathrm{Zn}$. Perna et al. [41] report significant $(0.01<p<0.001)$ correlation coefficients for DPPH and FRAP with Fe $(r=0.67$ and $r=0.73)$ and $\mathrm{Zn}(\mathrm{r}=0.32$ and $\mathrm{r}=0.48)$ in honey from Italy.

\subsection{Principal Component Analysis}

\subsubsection{Antioxidant Activity and Colour}

For a more in-depth analysis of the results obtained for the antioxidant activity and colour of the honey types, a principal component analysis (PCA) was performed, with 7 variables and 64 cases. Two principal components with eigenvalues exceeding 1 (Kaiser criterion) explained $87.12 \%$ of the total variance, with PC 1 accounting for $46.58 \%$ and PC 2 for $40.53 \%$ (Table S1).

Figure 1a visualizes the projection of variables as a two-factor plane $(\mathrm{PC} 1 \times \mathrm{PC} 2)$. The first component (PC1) has a positive correlation with $\mathrm{L}^{*}(0.828)$ and $\mathrm{h}^{\circ}(0.846)$, but a negative correlation with DPPH $(-0.723)$ and a moderate negative correlation with FRAP (-0628). The second component (PC2) has a negative correlation with most variables, including $\mathrm{a}^{*}(-0.897), \mathrm{C}^{*}(-0.740), \mathrm{b}^{*}(-0.708)$, and FRAP $(-0.654)$ (Table 3$)$.

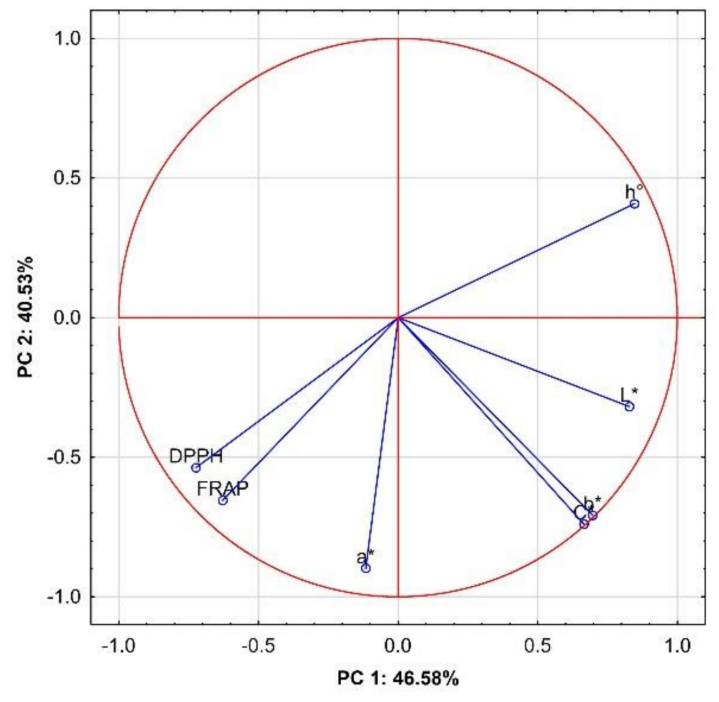

(a)

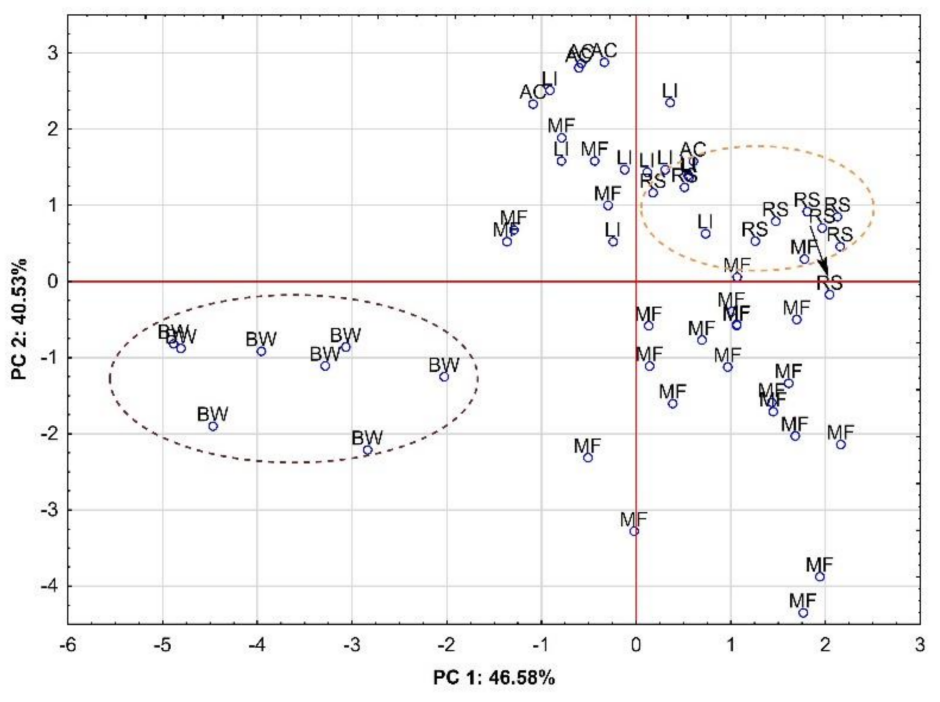

(b)

Figure 1. Projection of variables (a) and projection of cases (b) depending on the botanical origin of the honey in a two-factor plane $(\mathrm{PC} 1 \times \mathrm{PC} 2) .(\mathbf{a})$ : $\mathrm{L}^{*}$, lightness; $\mathrm{a}^{*}$, redness; $\mathrm{b}^{*}$, yellowness; $\mathrm{C}^{*}$, saturation; $\mathrm{h}^{\circ}$, hue angle; $\mathrm{DPPH}$, scavenging capacity; FRAP, ferric reducing antioxidant power; (b) honey type: RS, rapeseed; BW, buckwheat; LI, linden; AC, black locust; MF, multifloral. 
Table 3. Correlations between the principal components and the original variables.

\begin{tabular}{ccc}
\hline Variable & PC1 & PC2 \\
\hline $\mathrm{L}^{*}$ & 0.828 & -0.318 \\
$\mathrm{a}^{*}$ & -0.116 & -0.897 \\
$\mathrm{~b}^{*}$ & 0.667 & -0.708 \\
$\mathrm{C}^{*}$ & 0.665 & -0.740 \\
$\mathrm{~h}^{\circ}$ & 0.846 & 0.408 \\
FRAP & -0.628 & -0.654 \\
DPPH & -0.723 & -0.537 \\
\hline
\end{tabular}

$\mathrm{L}^{*}$, lightness; $\mathrm{a}^{*}$, redness; $\mathrm{b}^{*}$, yellowness; $\mathrm{C}^{*}$, saturation; $\mathrm{h}^{\circ}$, hue angle; $\mathrm{DPPH}$, scavenging capacity; FRAP, ferric reducing antioxidant power.

As can be seen in Figure 1, three groups of parameters, characterized by their loadings and the length of the directional vectors can be distinguished. The $\mathrm{L}^{*}, \mathrm{~b}^{*}$ and $\mathrm{C}^{*}$ variables were distributed in the positive area of $\mathrm{PC} 1$ and negative area of $\mathrm{PC} 2$, while $\mathrm{h}^{\circ}$ is located in positive areas of both components, and $\mathrm{a}^{*}, \mathrm{DPPH}$ and FRAP have negative values of PC1 and PC2.

Figure $1 \mathrm{~b}$ shows the projection of cases depending on the botanical origin of the honey in the coordinate system defined by PC1 $\times$ PC2. The buckwheat honey samples are clearly separated and situated in the bottom left area of the plot, i.e., they have negative values of both components. Therefore, the buckwheat honey located in this square of the plot showed the highest values of antioxidant activity and redness $\left(\mathrm{a}^{*}\right)$, together with the lowest value of $h^{\circ}$, which was negatively correlated with FRAP and DPPH (Table 2). Among other honey types, the second group is composed of rapeseed samples (RS) in the upper right square of the plot, which is positively correlated with both components and represents the highest values of $\mathrm{L}^{*}$ and $\mathrm{h}^{\circ}$. In contrast, the samples of multifloral (MF) honey were more scattered, while the black locust (AC) and linden (LI) samples were generally positively correlated with PC2. Summing up, the data presented in Figure 1 confirm the results given in Tables 1 and 2. Buckwheat honey showed the highest antioxidant activity together with the greatest redness and the lowest value of $\mathrm{h}^{\circ}$.

Kaczmarek et al. [6], based on the cluster analysis dendrogram, have distinguished two well-separated clusters of eight types of Polish honeys. The first cluster included dark honeys (nectar-honeydew, buckwheat, honeydew, and heather), while the second one contained light coloured honeys (acacia, rape, linden, and multiforal).

\subsubsection{Antioxidant Activity and Minerals}

Another PCA analysis (including 9 variables and 64 cases) was conducted on the results obtained for antioxidant activity and the concentrations of selected minerals and trace elements. Three principal components with eigenvalues exceeding 1 (Kaiser criterion) explained $73.46 \%$ of the total variance, with PC1 accounting for $40.65 \%$, PC2 for $18.24 \%$, and PC3 for $14.57 \%$ (Table S2). Figure 2a visualizes the projection of variables onto a two-factor plot $(\mathrm{PC} 1 \times \mathrm{PC} 2)$, explaining $58.89 \%$ of the total variance. The variables were distributed in two-quarters of the plot. The first area (bottom right quarter) included $\mathrm{Cu}$, $\mathrm{Mn}, \mathrm{DPPH}, \mathrm{FRAP}$ and Fe, positively correlated with PC1 $(0.893,0.808,0.772,0.697$ and 0.596 ) (Table 4). The second area (upper right quarter) included $\mathrm{K}$ and $\mathrm{Mg}$, which were positively correlated with PC2 (0.725 and 0.708, respectively). The third component was positively correlated with $\mathrm{Na}$ and $\mathrm{Zn}(0.760$ and 0.433$)$.

Figure $2 \mathrm{~b}$ shows the projection of cases depending on the botanical origin of the honey in the coordinate system defined by the first two principal components (PC1 $\times$ PC2). With the exception of buckwheat honey, the honey types were characterized by high dispersion of samples in the plot. Samples of buckwheat honey were found only in the bottom right square, i.e., positively correlated with PC1 and negatively with PC2. Thus, buckwheat (BW) honey showed strong antioxidant activity, together with a high concentration of $\mathrm{Mn}$ and $\mathrm{Cu}$. Based on analysis of the content of selected minerals and trace elements in various types of Italian honeys, it was confirmed that their botanical origin significantly influenced 
their chemical composition, particularly in the case of $\mathrm{Ca}, \mathrm{Na}$ and $\mathrm{Mn}$ [18]. Furthermore, PCA analysis indicated correlations between the concentration of minerals and the type of honey, as the highest element concentrations were found in the darkest honeys (honeydew) and the lowest content in light-coloured samples. Similar relationships between mineral concentration ( $\mathrm{Fe}, \mathrm{Zn}$ and $\mathrm{Mn}$ ) and pine honeydew (dark) and acacia (light) were reported for honeys from Kashmir [7]. The results of our research confirm these dependencies for buckwheat honey from Poland.

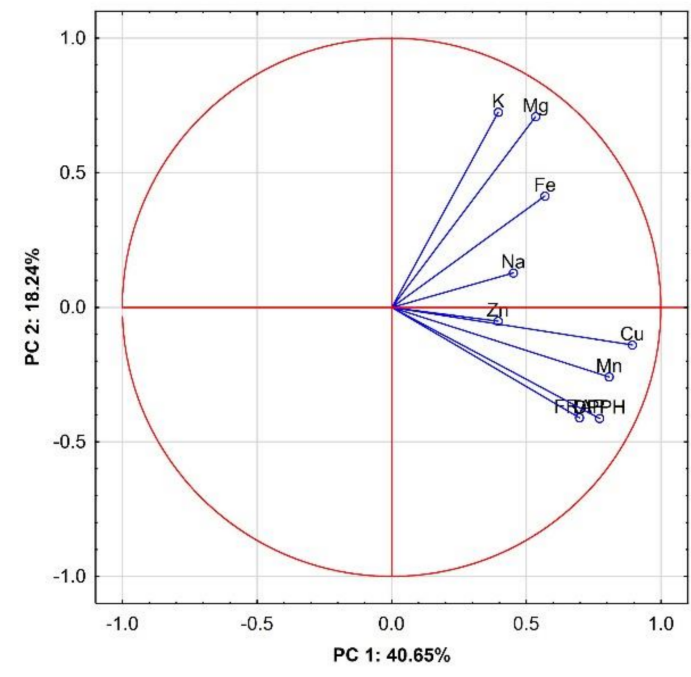

(a)

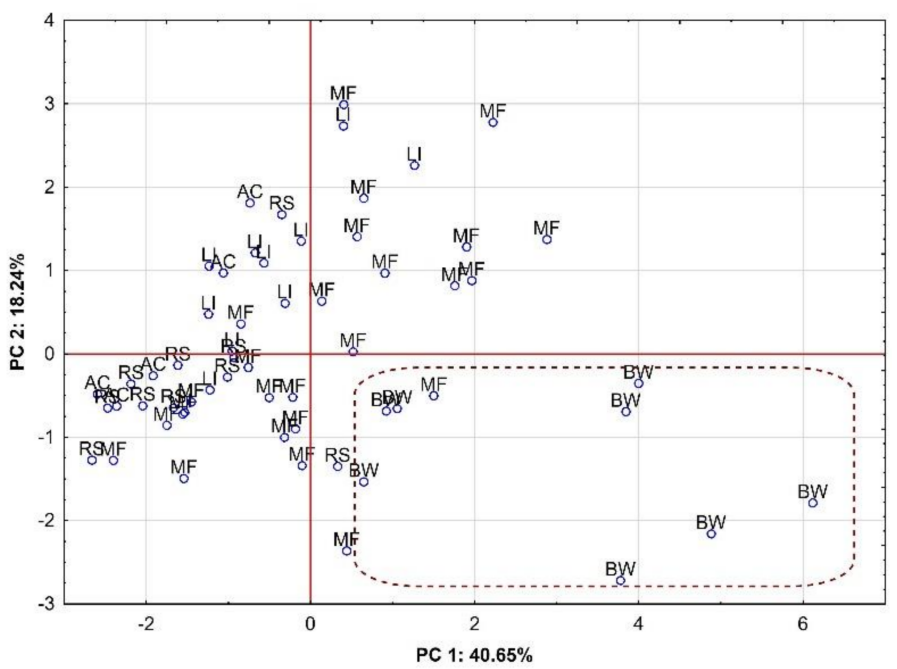

(b)

Figure 2. Projection of variables (a) and projection of cases (b) depending on the botanical origin of the honey in a two-factor plane (PC1 × PC2). (a) K, potassium; Na, sodium; Mg, magnesium; Fe, iron; Zn, zinc; Mn, manganese; Cu, copper; DPPH, scavenging capacity; FRAP, ferric reducing antioxidant power; (b) honey type: RS, rapeseed; BW, buckwheat; LI, linden; AC, black locust; MF, multifloral.

Table 4. Correlations between the principal components and the original variables.

\begin{tabular}{cccc}
\hline Variable & PC1 & PC2 & PC3 \\
\hline $\mathrm{K}$ & 0.396 & 0.725 & -0.394 \\
$\mathrm{Mg}$ & 0.535 & 0.708 & -0.264 \\
$\mathrm{Na}$ & 0.451 & 0.128 & 0.760 \\
$\mathrm{Fe}$ & 0.596 & 0.413 & 0.467 \\
$\mathrm{Zn}$ & 0.395 & -0.051 & 0.433 \\
$\mathrm{Cu}$ & 0.893 & -0.140 & -0.093 \\
$\mathrm{Mn}$ & 0.808 & -0.259 & -0.170 \\
$\mathrm{FRAP}$ & 0.697 & -0.410 & -0.156 \\
$\mathrm{DPPH}$ & 0.772 & -0.413 & -0.200 \\
\hline
\end{tabular}

$\mathrm{K}$, potassium; $\mathrm{Na}$, sodium; $\mathrm{Mg}$, magnesium; $\mathrm{Fe}$, iron; $\mathrm{Zn}$, zinc; $\mathrm{Mn}$, manganese; $\mathrm{Cu}$, copper; $\mathrm{DPPH}$, scavenging capacity; FRAP, ferric reducing antioxidant power.

\section{Conclusions}

The study demonstrated that the physicochemical properties, instrumental colour parameters, content of some elements, and antioxidant activity of five honey types from Poland were significantly influenced by their botanical origin. Strong relationships were shown between antioxidant activity and parameters of instrumental CIE L*a* $b^{*}$ colour analysis, as well as antioxidant minerals. The principal component analysis allowed the types to be classified in terms of their antioxidant activity in combination with their colour characteristics and content of certain elements. The buckwheat honeys, which were the darkest, had the strongest antioxidant activity, which may have been linked to the fact that they had the highest concentrations of copper, manganese and zinc. These parameters can 
be potentially used for the identification of buckwheat honeys from other blossom types. However, this requires further studies with honeys of different geographical origins.

Supplementary Materials: The following are available online at https:/ /www.mdpi.com/article/10 .3390 /agriculture11080702/s1, Table S1: Eigenvalues and the proportion of variation (\%) explained by 7 principal components, Table S2: Eigenvalues and the proportion of variation (\%) explained by 9 principal components.

Author Contributions: Conceptualization, M.K.-M. and M.F.; methodology, M.K.-M., A.T., M.S. and M.R.; investigation, A.T., M.S., P.D. and M.R.; formal analysis, M.K.-M. and M.F.; data curation, M.S., P.S., P.D. and M.R.; writing original draft, M.K.-M., A.T., M.S., P.D. and M.R.; writing-review \& editing, P.S. and M.F.; funding acquisition, P.S.; project administration, P.S.; supervision, M.F. All authors have read and agreed to the published version of the manuscript.

Funding: This research was funded under the program of the Minister of Science and Higher Education under the name "Regional Initiative of Excellence" in 2019-2022 project number 029/RID/2018/19 funding amount 11,927,330.00 PLN.

Institutional Review Board Statement: Not applicable.

Data Availability Statement: Data sharing not applicable.

Conflicts of Interest: The authors declare no conflict of interest. The funders had no role in the design of the study; in the collection, analyses, or interpretation of data; in the writing of the manuscript, or in the decision to publish the results.

\section{References}

1. Rao, P.V.; Krishnan, K.T.; Salleh, N.; Gan, S.H. Biological and therapeutic effects of honey produced by honey bees and stingless bees: A comparative review. Rev. Bras. Farmacogn. 2016, 26, 657-664. [CrossRef]

2. Kuś, P.; Congiu, F.; Teper, D.; Sroka, Z.; Jerković, I.; Tuberoso, C.I.G. Antioxidant activity, color characteristics, total phenol content and general HPLC fingerprints of six Polish unifloral honey types. LWT-Food Sci. Technol. 2014, 55, 124-130. [CrossRef]

3. Kędzierska-Matysek, M.; Florek, M.; Wolanciuk, A.; Barłowska, J.; Litwińczuk, Z. Concentration of Minerals in Nectar Honeys from Direct Sale and Retail in Poland. Biol. Trace Elem. Res. 2018, 186, 579-588. [CrossRef]

4. da Silva, P.M.; Gauche, C.; Gonzaga, L.V.; Oliveira Costa, A.C.; Fett, R. Honey: Chemical composition, stability and authenticity. Food Chem. 2016, 196, 309-323. [CrossRef] [PubMed]

5. Álvarez-Suárez, J.M.; Tulipani, S.; Díaz, D.; Estevez, Y.; Romandini, S.; Giampieri, F.; Damiani, E.; Astolfi, P.; Bompadre, S.; Battino, M. Antioxidant and antimicrobial capacity of several monofloral Cuban honeys and their correlation with color, polyphenol content and other chemical compounds. Food Chem. Toxicol. 2010, 48, 2490-2499. [CrossRef] [PubMed]

6. Kaczmarek, A.; Muzolf-Panek, M.; Tomaszewska-Gras, J.; Konieczny, P. Predicting the Botanical Origin of Honeys with Chemometric Analysis According to Their Antioxidant and Physicochemical Properties. Pol. J. Food Nutr. Sci. 2019, 69, $191-201$. [CrossRef]

7. Nayik, G.A.; Nanda, V. Physico-Chemical, Enzymatic, Mineral and Colour Characterization of Three Different Varieties of Honeys from Kashmir Valley of India with a Multivariate Approach. Pol. J. Food Nutr. Sci. 2015, 65, 101-108. [CrossRef]

8. Voica, C.; Iordache, A.M.; Ionete, R.E. Multielemental characterization of honey using inductively coupled plasma mass spectrometry fused with chemometrics. J. Mass Spectrom. 2020, 55, e4512. [CrossRef]

9. Akbulut, M.; Özcan, M.M.; Çoklar, H. Evaluation of antioxidant activity, phenolic, mineral contents and some physicochemical properties of several pine honeys collected from Western Anatolia. Int. J. Food Sci. Nutr. 2009, 60, 577-589. [CrossRef]

10. Gheldof, N.; Engeseth, N.I. Antioxidant capacity of honeys from various flora sources based on the determination of oxygen radical absorbance capacity and inhibition of in vitro lipoproteid oxidation in human serum samples. J. Agric. Food Chem. 2002, 50, 3050-3055. [CrossRef]

11. Socha, R.; Juszczak, L.; Pietrzyk, S.; Gałkowska, D.; Fortuna, T.; Witczak, T. Phenolic profile and antioxidant properties of Polish honeys. Int. J. Food Sci. Technol. 2011, 46, 528-534. [CrossRef]

12. Israili, Z.H. Antimicrobial properties of honey. Am. J. Therap. 2014, 21, 304-323. [CrossRef]

13. Cianciosi, D.; Forbes-Hernández, T.Y.; Afrin, S.; Gasparrini, M.; Reboredo-Rodriguez, P.; Manna, P.P.; Zhang, J.; Bravo Lamas, L.; Martínez Flórez, S.; Agudo Toyos, P.; et al. Phenolic Compounds in Honey and Their Associated Health Benefits: A Review. Molecules 2018, 23, 2322. [CrossRef]

14. EU Council Directive 2001/110/EC of 20 December 2001 relating to honey. Off. J. EU 2002, L10, 47-52. Available online: http:/ / data.europa.eu/eli/dir/2001/110/2014-06-23 (accessed on 8 November 2020).

15. Kędzierska-Matysek, M.; Florek, M.; Wolanciuk, A.; Skałecki, P. Effect of freezing and room temperatures storage for 18 months on quality of raw rapeseed honey (Brassica napus). J. Food Sci. Technol. 2016, 53, 3349-3355. [CrossRef] [PubMed] 
16. Kędzierska-Matysek, M.; Florek, M.; Wolanciuk, A.; Skałecki, P.; Litwińczuk, A. Characterisation of viscosity, colour, 5hydroxymethylfurfural content and diastase activity in raw rape honey (Brassica napus) at different temperatures. J. Food Sci. Technol. 2016, 53, 2092-2098. [CrossRef] [PubMed]

17. Reshma, K.; Thasniya, M.; Gopika, S.K.; Arunima, S.H. Honey crystallization: Mechanism, evaluation and application. Pharma Innov. 2021, 10, 222-231. [CrossRef]

18. Pisani, A.; Protano, G.; Riccobono, F. Minor and trace minerals in different honey types produced in Siena County (Italy). Food Chem. 2008, 107, 1553-1560. [CrossRef]

19. MARD. Regulation of the Minister of Agriculture and Rural Development of 14 January 2009 on the methods of analysis related to the assessment of honey. J. Laws 2009, 17, 2018-2030.

20. Bogdanov, S.; Martin, P.; Lüllmann, C. Harmonised methods of the European Honey Commission. Apidologie 2009, 1-59. Available online: http:/ / www.ihc-platform.net/ihcmethods2009.pdf (accessed on 28 December 2020).

21. White, J. Spectrophotometric method for hydroxymethylfurfural in honey. J. Assoc. Off. Anal. Chem. 1979, 62, 509-514. [CrossRef]

22. Blois, M.S. Antioxidant determinations by the use of a stable free radical. Nature 1958, 181, 1199-1200. [CrossRef]

23. Bertoncelj, J.; Doberšek, U.; Jamnik, M.; Golob, T. Evaluation of the phenolic content, antioxidant activity and colour of Slovenian honey. Food Chem. 2007, 105, 822-828. [CrossRef]

24. Tornuk, F.; Karaman, S.; Ozturk, I.; Toker, O.S.; Tastemur, B.; Sagdic, O.; Dogan, M.; Kayacier, A. Quality characterization of artisanal and retail Turkish blossom honeys: Determination of physicochemical, microbiological, bioactive properties and aroma profile. Ind. Crops Prod. 2013, 46, 124-131. [CrossRef]

25. Kacaniova, M.; Knazovicka, W.; Melich, M.; Fikselova, M.; Massanyi, P.; Stawarz, R.; Hascik, P.; Pechociak, T.; Kuczkowska, A.; Putała, A. Environmental concentration of selected elements and relation to physicochemical parameters in honey. J. Environ. Sci. Health Part A 2009, 44, 414-422. [CrossRef] [PubMed]

26. Cavia, M.M.; Fernández-Muino, M.A.; Alonso-Torre, S.R.; Huidobro, J.F.; Sancho, M.T. Evolution of acidity of honeys from continental climates: Influence of induced granulation. Food Chem. 2007, 100, 1728-1733. [CrossRef]

27. Chen, C. Relationship between water activity and moisture content in floral honey. Foods 2019, 8, 30. [CrossRef] [PubMed]

28. Serrano, S.; Espejo, R.; Villarejo, M.; Jodral, M.J. Diastase and invertase activities in Andalusian honeys. Int. J. Food Sci. Technol. 2007, 42, 76-79. [CrossRef]

29. Wesołowska, M.; Dżugan, M. Activity and thermal stability of diastase present in honey from Podkarpacie Region. Food Sci. Technol. Qual. 2017, 24, 103-112. Available online: http://wydawnictwo.pttz.org/wp-content/uploads/2018/03/09_Wesolowska. pdf (accessed on 6 December 2020).

30. Kek, S.P.; Chin, N.L.; Tan, S.W.; Yusof, Y.A.; Chua, L.S. Classification of Honey from Its Bee Origin via Chemical Profiles and Mineral Content. Food Anal. Methods 2017, 10, 19-30. [CrossRef]

31. Ördög, A.; Tari, I.; Bátori, Z.; Poór, P. Mineral content analysis of unifloral honeys from the Hungarian Great Plain. J. Elem. 2017, 22, 271-281. [CrossRef]

32. Wieczorek, J.; Pietrzak, M.; Pomianowski, J.; Wieczorek, Z. Honey as a source of bioactive compounds. Pol. J. Nat. Sci. 2014, 29, 275285. Available online: http://www.uwm.edu.pl/polish-journal/sites/default/files/issues/articles/wieczorek_et_al._2014.pdf (accessed on 6 December 2020).

33. Dżugan, M.; Zaguła, G.; Wesołowska, M.; Sowa, P.; Puchalski, C. Levels of Toxic and Essential Metals in Varietal Honeys from Podkarpacie. J. Elem. 2017, 22, 1039-1048. [CrossRef]

34. Deng, J.; Liu, R.; Lu, Q.; Hao, P.; Xu, A.; Zhang, J.; Tan, J. Biochemical properties, antibacterial and cellular antioxidant activities of buckwheat honey in comparison to manuka honey. Food Chem. 2018, 252, 243-249. [CrossRef] [PubMed]

35. Škrovánková, S.; Snopek, L.; Mlček, J.; Volař́iková, E. Bioactive Compounds Evaluation in Different Types of Czech and Slovak Honeys. Potravin. Slovak J. Food Sci. 2019, 13, 94-99. [CrossRef]

36. Cheng, N.; Wu, L.; Zheng, J.; Cao, W. Buckwheat Honey Attenuates Carbon Tetrachloride-Induced Liver and DNA Damage in Mice. Evid. Based Complementary Altern. Med. 2015, 2015, 987385. [CrossRef]

37. Piszcz, P.; Głód, B.K. Antioxidative Properties of Selected Polish Honeys. J. Apic. Sci. 2019, 63, 81-91. [CrossRef]

38. Dżugan, M.; Tomczyk, M.; Sowa, P.; Grabek-Lejko, D. Antioxidant Activity as Biomarker of Honey Variety. Molecules 2018, 23, 2069. [CrossRef] [PubMed]

39. Moniruzzaman, M.; Sulaiman, S.A.; Khalil, M.I.; Gan, S.H. Evaluation of physicochemical and antioxidant properties of sourwood and other Malaysian honeys: A comparison with manuka honey. Chem. Cent. J. 2013, 7, 138. [CrossRef]

40. Beretta, G.; Granata, P.; Ferrero, M.; Orioli, M.; Maffei Facino, R. Standardization of antioxidant properties of honey by combination of spectrophotometricfluorimetric assays and chemometrics. Anal. Chim. Acta 2005, 533, 185-191. [CrossRef]

41. Perna, A.; Simonetti, A.; Intaglietta, I.; Sofo, A.; Gambacorta, E. Metal content of southern Italy honey of different botanical origins and its correlation with polyphenol content and antioxidant activity. Int. J. Food Sci. Technol. 2012, 47, 1909-1917. [CrossRef] 